\title{
DiAlog I RELACJE MiĘDZY DORASTAJĄCYMI DZIEĆMI A RODZICAMI NA PODSTAWIE BADAŃ PRZEPROWADZONYCH W V LICEUM Ogólnoksztaecącym w Krakowie
}

\author{
Aleksandra Guśpiel, e-mail: aleksandra.guspiel@gmail.com \\ Akademia Ignatianum w Krakowie \\ ul. Kopernika 26, 31-501 Kraków
}

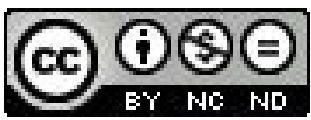

\section{STRESZCZENIE}

Artykuł prezentuje badania empiryczne przeprowadzone we wrześniu 2013 r. w klasach maturalnych małopolskiej elitarnej szkoły średniej - V Liceum Ogólnokształcacego im. Augusta Witkowskiego w Krakowie. Tekst ukazuje opinie dorastających dzieci na temat relacji interpersonalnych łączących ich z rodzicami oraz zgłębia zagadnienie dialogu we współczesnych polskich rodzinach wielkomiejskich. Artykuł przedstawia jakość i zakres tegoż dialogu - zatem może być to zarówno dialog oparty na partnerstwie i podmiotowym traktowaniu, jak i pseudodialog, w którym brak wzajemności, szczerości, akceptacii, umiejętności słuchania, zaangażowania, cierpliwości.

Słowa kluczowe: wychowanie, rodzina, dialog, relacje interpersonalne, podmiotowe traktowanie

Dialogue and interpersonal relations between adolescents and their parents based on research done in $\mathrm{V}$ high school in Kraków

\section{Abstract}

Paper presents empirical study made on senior class in V high school in Kraków, one of the most prestigious high schools in Lesser Poland. Paper shows adolescents opinion on their relationship with parents. Article focuses on quality and scope of the dialogue in modern polish big-city families. Dialogue can either be based on partnership and respect dignity of the child, or it can be a pseudo-dialogue which lacks honesty, acceptance, patience, involvement and ability to listen.

Key words: upbringing, family, dialogue, interpersonal relations, respect for dignity of the child

\section{SŁOWEM WSTĘPU}

Niniejszy artykuł powstał w oparciu o pracę magisterską Dialog rodziców z dorastającymi dziećmi w środowisku wielkomiejskim na podstawie badan przeprowadzonych wśród uczniów V Liceum Ogólnokształcacego imienia Augusta Witkowskiego w Krakowie. Celem artykułu jest popularyzowanie otrzymanych wyników badań, zaktualizowanie wiedzy o dialogu i relacjach między rodzicami a dorastającymi dziećmi, a także ukazanie, jak z punktu widzenia maturzystów V LO im. Augusta Witkowskiego w Krakowie wyglądają wspomniane kwestie. Tekst ma również na celu rozstrzygnięcie, czy elitarność szkoły idzie w parze z dobrymi relacjami i postawą dialogu w rodzinach uczniów.

\section{WPROWADZENIE}

Człowiek ze swej natury jest istotą społeczną. Od pierwszych chwil otoczony jest ludźmi, dzięki którym może żyć, prawidłowo się rozwijać, uczyć się, naśladować ich, kochać. Dziecko potrzebuje wsparcia, kierownictwa i miłości innych, a także wychowania, które jest szczególną formą spotkania i dialogu między wychowującym i wychowywanym ${ }^{1}$, procesem wspomagającym jego rozwój i kształtującym osobowośćc. Stąd ważną rolę w życiu dziecka odgrywa rodzina, która, jak podkreśla Helena Izdebska, jest podstawowym środowiskiem życia i wychowania młodego pokolenia ${ }^{3}$.

Wychowanie to przyniesie szczególnie dobre efekty, kiedy rodzice zatroszczą się o relacje interpersonalne ze swymi dziećmił. Wielu autorów podkreśla, iż matki i ojcowie powinni wchodzić ze swoimi dziećmi w relację dialogu, opartą o podmiotowe traktowanie, a tym samym przekazać im właściwe wzory komunikowania się. Violetta Kruczkowska

1 Zob. A. Cosmopoulos, Edukacja jako relacja interpersonalna - spojrzenie aktualne, „Kwartalnik Pedagogiczny” 2001, nr 2, s. 8.

2 Zob. A. Błasiak, Oddziaływania wychowawcze w rodzinie. Zagadnienia woybrane, Kraków 2012, s. 65.

3 H. Izdebska, Rodzina i jej funkcje wychowaawcze, [w:] W. Pomykało (red.), Encyklopedia pedagogiczna, Warszawa 1993, s. 698.

4 Zob.A. Cosmopoulos, dz. cyt., s. 8. 
przekonuje, iż do wielu problemów w relacjach rodziców z dorastającymi dziećmi przyczynia się nieumiejętność prowadzenia przez rodziców rozmów. Dorośli często nie potrafią pogodzić się z tym, iż ich dziecko może mieć odmienne zdanie - wówczas krzycza, groża, obwiniaja, osądzaja, oceniaja, poniżają, za wszelką cenę chcą zajmować pozycję dominującą. Takie zachowanie rani dziecko, uwłacza godności dorastającego, poniża go i przyczynia się do odwetu z jego strony. Wzajemne ranienie się wpływać będzie na pogorszenie się relacji, oddalanie się od siebie, a także pojawianie się poczucia niezrozumienia, braku akceptacji 5 .

Tymczasem postawa dialogu kształtuje się na podłożu, jakim są właściwe i bliskie relacje interpersonalne. „Dialog jest najlepszym sposobem na pełne, prawdziwie ludzkie, personalne spotkanie człowieka z człowiekiem" ${ }^{\prime \prime}$. Dodatkowo charakteryzowaćbędzie się tym, iż razjesteśmy w roli mówiącego, raz słuchającego. Zatem dialog zakłada wystuchiwanie drugiej strony, branie pod uwagę zdania partnera dialogu i akceptowanie jego punktu widzenia, traktowanie go na równi, bez atakowania, narzucania swoich racji, obrażania go. Marian Śnieżyński dialog określa jako „sposób komunikacji i relacji interpersonalnych pomiędzy współmałżonkami oraz dziećmi i rodzicami, w której podmioty (dzieci - rodzice) dążą w szczególny sposób przez słowo, ale i przez gesty, do wzajemnego zrozumienia, zbliżenia i współdziałania, w wyniku którego możliwe staje się ustalenie ram wzajemnego kompromisu prowadzącego do poznania prawdy, dobra i piękna"7 .

Relacja osobowa to wzajemne dzielenie się sobą (swoimi refleksjami, przekonaniami), współprzeżywanie. Zakłada otwarcie się na drugiego i przyjęcie go takiego, jakim jest - bezwarunkowo. Kluczowa dla zaistnienia relacji osobowej jest wzajemność między podmiotami - obie strony muszą wykazać chęć i otwartość na siebie i na wspólny dialog - bez przymusus.

W dialogu, tak jak i w relacji, ważne jest podmiotowe traktowanie. Każdy z partnerów relacji jest podmiotem, jest równie ważny i należy mu się szacunek, bez względu na wiek -czy jest dorosłym człowiekiem i rodzicem czy może dorastającym dzieckiem.

\section{METOdOLOGIA BADAŃ WŁASNYCH}

Problem główny w przeprowadzonych badaniach brzmiał: Jaki jest wymiar i zakres stosowanego przez rodziców dialogu wychowawczego w odniesieniu do swoich dorastających dzieci? Dalej wysunięto następujące problemy szczegółowe:

- Jak kształtują się relacje interpersonalne dorastających i ich rodziców?

- Czy i w jakim zakresie w procesie wychowania uwzględniany jest dialog?

W obrębie pedagogiki funkcjonuje wiele różnych typologii badań pedagogicznych. Mieczysław Łobocki wyróżnia: metodę obserwacji, metodę szacowania, eksperyment pedagogiczny, testy osiągnięć szkolnych, metodę socjometryczna, analizę dokumentów, metodę sondażu, metodę dialogową oraz metodę biograficzną. Jednak, jak twierdzi, wciąż nie jest to podział wyczerpujący9. Teresa Bauman i Tadeusz Pilch wskazują na cztery metody prowadzenia badań pedagogicznych: eksperyment pedagogiczny, monografię pedagogiczna, metodę indywidualnych przypadków oraz sondaż diagnostyczny ${ }^{10}$. W badaniach postużono się metodą sondażu diagnostycznego. Służy ona do gromadzenia wiedzy o opiniach, poglądach wybranych zbiorowości. Pomaga rozeznać się w dynamice zjawisk społecznych - kierunkach zmian, tendencjach ${ }^{11}$. Dzięki zastosowaniu sondażu diagnostycznego możliwe było z jednej strony zaobserwowanie istniejących skłonności w budowaniu relacji czy w prowadzeniu dialogu pomiędzy dorastającą młodzieżą a rodzicami, z drugiej zaś poznanie opinii badanych w obrębie wspomnianych kwestii.

Badania dotyczące rodziny wielokrotnie były już prowadzone. Jednak za punkt wyjścia posłużyło założenie, że rodziny i warunki, w jakich przychodzi im żyć, zmieniają się w bardzo dynamiczny sposób, co rodzi ciagłą potrzebę wznawiania tematu. Obecnie obserwujemy wiele zjawisk zagrażających rodzinie. Zbigniew Tyszka wskazuje m.in. na: wzrost zatrudnienia kobiet, zmniejszenie wartości dzieci dla rodziców, wypieranie wartości tradycyjnych, indywidualizację i autonomizacjęc członków rodziny, mniejszą spójność i dezintegrację rodzin, wzrost liczby konfliktów w małżeństwie, wzrost

\footnotetext{
5 V. Kruczkowska, Komunikacja z nastolatkiem, „,Wychowawca” 2012, nr 7-8, s. 29.

6 M. Śnieżyński, Zarys dydaktyki dialogu, Kraków 1997, s. 133.

7 M. Śnieżyński, Dialog w rodzinie, http://www.opoka.org.pl/biblioteka/Z/ZR/wam_2012_dialog_02.html\#p19, 21.05.2013.

8 Zob. A. Cosmopoulos, dz. cyt., s. 8-9.

9 Zob. M. Łobocki, Metody i techniki badań pedagogicznych, Kraków 2000, s. 30-31.

10 T. Bauman, T. Pilch, Zasady badań pedagogicznych. Strategie ilościowe i jakościowe, Warszawa 2001, s.72.

11 Zob. Tamże, s. 79-81.
} 
liczby rozwodów, spadek ilości związków sformalizowanych i jednoczesny wzrost związków kohabitacyjnych ${ }^{12}$. Anna Błasiak zauważa, iż poprzez rozwój mass mediów żyjemy w natłoku informacji, które wprowadzają do naszego życia chaos $^{13}$. Autora niniejszego artykułu zastanawiało, jak w takim kontekście, w Krakowie, w środowisku wielkomiejskim, kształtują się relacje i dialog pomiędzy rodzicami a dziećmi. Szczególnie istotnym do zbadania wydał się okres dojrzewania dziecka, po którym następuje dorosłość, a wraz z nią moment opuszczenia domu rodzinnego. Jeśli dziecko opuści dom, wynosząc z niego złe wspomnienia, nie będąc związanym bliskimi, przyjacielskimi relacjami z rodzicami, najprawdopodobniej nie będzie chciało do domu rodzinnego wracać. Ponadto, jeśli do momentu dorosłości (w relacjach z rodzicami) dziecko nie nauczy się wchodzenia w bliskie relacje, prowadzenia dialogu, rozwiązywania konfliktów, to najprawdopodobniej będzie miało z tym trudności także w życiu dorosłym. Chodzi tu o tzw. transmisję międzypokoleniową ${ }^{14}$.

Przeprowadzając badania, posłużono się trzema technikami. Pierwszą z nich jest ankieta, w obrębie której zastosowano narzędzie - kwestionariusz ankiety. Składał się on z dwóch części - A i B. Pierwsza z nich (część A) zawiera 15 pytań dotyczących płci, warunków bytowych i kulturowych respondentów. Natomiast część B składa się z 34 pytań. Dotyczą one przede wszystkim dialogu i relacji między badaną młodzieżą a ich rodzicami. Pytania w kwestionariuszu miały charakter zamknięty, półotwarty lub otwarty. Pytania zamknięte przynoszą materiał w znacznym stopniu ujednolicony i zestandaryzowany, jednak zakładają z góry pewien zestaw odpowiedzi, przez co nie dają respondentowi szansy swobodnego wypowiedzenia się. Pytania otwarte zaś są szczególnie wartościowe, gdyż pozostawiają badanym całkowitą swobodę odpowiedzi, dzięki czemu umożliwiają bardziej osobiste i niepowierzchowne wyznania' ${ }^{15}$. Obok tych dwóch rodzajów pytań wykorzystano także pytania półotwarte, gdzie poza wyborem spośród kilku sugerowanych odpowiedzi, respondent miał miejsce na wpisanie własnych, dodatkowych odpowiedzi ${ }^{16}$.

Głównym powodem posłużenia się w badaniach ankietą była możliwość poznania opinii dużej liczby badanych osób w bardzo krótkim czasie, bez konieczności kontaktu bezpośredniego z respondentami. Wspomniana technika posiada jednak i wady - badania prowadzone za jej pomocą są powierzchowne - nie dają możliwości zaobserwowania złożonych problemów środowiskowych ${ }^{17}$. Stąd też badacz wspomógł się innymi technikami, aby bardziej obiektywnie przedstawić rzeczywistość. I tak zastosowano technikę projekcyjna, werbalna, polegająca na kończeniu zdań. Dzięki niej można było poznać uczucia, reakcje badanej młodzieży w obrębie interesującego zagadnienia ${ }^{18}$. Narzędzie - kwestionariusz zdań niedokończonych, składało się z 22 zdań wymagających dokończenia. Niektóre spośród nich dotyczyły dialogu w rodzinie, inne natomiast skupiały się wokół relacji, jakie łączą dorastające dziecko z rodzicami.

Kolejną techniką uzupełniającą była analiza dokumentów. I tutaj posłużono się narzędziem - wypracowanie uczniowskie na temat Rodzina moich marzeń. Technika ta daje badanym dużą swobodę i pozwala na spontaniczność przy formułowaniu wypowiedzi pisemnych. Dzięki temu można było przyjrzeć się przeżyciom, doświadczeniom badanych związanym zjakością i zakresem prowadzonego (bądźnie) dialogu, a także relacjami, jakie łączą ich z rodzicami. Ponadto analiza wypracowań uczniowskich jest niezwykle wartościowa przy jakościowym opisie badanego problemu ${ }^{19}$. Narzędzia, które zastosowano prowadząc badania empiryczne, opracowane i udostępnione badaczowi zostały przez Mariana Śnieżyńskiego.

\section{GRUPA BADAWCZA}

Badania własne przeprowadzono w V Liceum Ogólnokształcącym im. Augusta Witkowskiego w Krakowie. Wybór takiego środowiska badań spowodowany był ciekawościa, jak układają się dialog oraz relacje interpersonalne między uczniami klas maturalnych a ich rodzicami w najbardziej renomowanym w Małopolsce liceum. Szkoła, o której mowa, powstała w 1871 r., jej dyrektorem od 1992 r. jest Stanisław Pietras. Niektóre klasy mają część zajęć prowadzoną na Uniwersytecie Jagiellońskim lub przez wykładowców tejże uczelni. Uczniowie V Liceum od wielu lat osiagają świetne wyniki w nauce, konkursach i olimpiadach przedmiotowych, co nieustannie owocuje przyznawaniem stypendiów MEN oraz

12 Z. Tyszka, Rodzina wspótczesna-jej geneza i kierunki przemian, [w:] M. Ziemska (red.), Rodzina wspótczesna, Warszawa 1999, s. 198.

13 A. Błasiak, dz. cyt., s. 130 .

14 Zob. A. Kałużna-Wielobób, J. K. Wielobób, Międzypokoleniowa transmisja konfliktów w rodzinie, „Społeczeństwo i Rodzina” 2013, nr 35, s. 79.

15 Zob. T. Bauman, T. Pilch, dz. cyt., s. 97.

16 Zob. M. Łobocki, Wprowadzenie do metodologii badan pedagogicznych, Kraków 2004, s. 252.

17 Zob. T. Bauman, T. Pilch, dz. cyt., s. 97-98.

18 Zob. Tamże, s. 102.

19 Zob. M. Łobocki, Wprowadzenie do metodologii badań pedagogicznych, Kraków 2004, s. 259. 
nagród edukacyjnych miasta Krakowa ${ }^{20}$. Jak donoszą miesięczniki „Perspektywy” oraz „Rzeczpospolita”, w ogólnopolskim rankingu szkół ponadgimnazjalnych od 2000 roku V Liceum zajmuje pierwsze miejsce w Małopolsce oraz znajduje się w pierwszej dziesiątce liceów w Polsce ${ }^{21}$. Świadczyć może to o niezwykle dużej renomie szkoły, a także specyfice tego środowiska, gdzie ogromny nacisk kładziony jest, zarówno przez rodziców, nauczycieli, jak i samych uczniów, na naukę, rozwój i dążenie do osiągnięcia sukcesu.

Badania empiryczne prowadzone były w środowisku wielkomiejskim, między 23. a 30. września $2013 \mathrm{r}$. W badaniu uczestniczyli uczniowie trzech klas trzecich (klasy maturalne) V Liceum o profilach: matematyczno-fizycznym, biologiczno-chemicznym oraz humanistycznym. Łącznie przebadano 102 osoby, jednak na drodze selekcji odrzucone zostały 24 prace, które były uzupełnione tylko częściowo. Ostatecznie próba reprezentacyjna liczyła 78 osób, co stanowi ok. 25\% maturzystów V LO. Spośród przebadanych osób 33 to dziewczyny, a pozostałe 45 to chłopcy.

\section{ChARAKTERYSTYKA ŚRODOWISKA BADANYCH UCZNióW}

Przejdę teraz do charakterystyki środowiska badanych uczniów w oparciu o uzyskane wyniki badań empirycznych. Należy zwrócić uwagę, że na jakość relacji interpersonalnych w rodzinie, a także na sposób komunikowania się rodziców z dziećmi, może oddziaływać sytuacja materialna rodziny. Kłopoty finansowe mogą być przyczyną trudności w realizacji podstawowych funkcji ogniska domowego. W rodzinach, które dotyka problem bezrobocia, panuje ciagły stres, niepewność o jutro, co wzmaga konflikty, kłótnie, przyczynia się do frustracji, nasila trudności wychowawcze ${ }^{22}$.

Tabela 1. Sytuacja materialna rodziny

\begin{tabular}{|l|l|l|}
\hline L.p. & Wyszczególnienie & Liczba \\
\hline 1 & Poniżej minimum socjalnego & 0 \\
\hline 2 & Na granicy minimum socjalnego & 0 \\
\hline 3 & Na przeciętnym poziomie materialnym (wystarcza do końca miesiąca) & 4 \\
\hline 4 & Nieco powyżej minimum socjalnego (brak problemów finansowych) & 32 \\
\hline 5 & Znacznie powyżej minimum socjalnego & 39 \\
\hline 6 & Nie wiem & 0 \\
\hline & Brak odpowiedzi & 3 \\
\hline
\end{tabular}

Źródło: opracowanie własne.

Tabela 1 obrazuje, jak badani uczniowie ocenili sytuację materialną swoich rodzin. Punktem odniesienia było minimum socjalne, które w 2012 roku wynosiło 456 złotych na osobę. Połowa badanych ocenia sytuację materialną swojej rodziny jako znacznie wyższą niż minimum socjalne. Żadna z badanych osób nie zadeklarowała, żejej rodzina żyje poniżej czy na granicy minimum socjalnego. Również żaden z licealistów nie stwierdził, że nie zna sytuacji materialnej swojej rodziny.

Można przypuszczać, że zdecydowana większość badanych ma bardzo dobrą sytuację materialna, wolną od kłopotów finansowych (91\%). Tymczasem według badań GUS, prowadzonych w 2011 roku ok. 15\% gospodarstw domowych na terenie Polski funkcjonuje w dostatku, a jedynie co pięćdziesiąta rodzina może sobie pozwolić na pewien luksus. Jednocześnie, jak można przeczytać w informatorze, aż 30 na 100 gospodarstw domowych funkcjonuje na co dzień raczej skromnie, a w $6 \%$ gospodarstw domowych pieniędzy nie starcza nawet na podstawowe potrzeby ${ }^{23}$. Obrazuje to, iż rodziny badanych uczniów wypadają korzystnie na tle ogólnej sytuacji materialnej polskich rodzin.

Dla sytuacji materialnej rodziny znaczenie może mieć także jej liczebność. Oczywiste bowiem wydaje się, iż utrzymanie jednego dziecka kosztuje mniej niż utrzymanie trójki. Ponadto liczba posiadanych dzieci może przekładać się na ilość czasu i jakość relacji między dzieckiem a matką czy ojcem.

20 V Liceum Ogólnokształcace wo Krakowie, http://www.v-lo.krakow.pl/o-szkole/historia-szkoly, 6.11.2013.

21 V Liceum Ogólnokształcace im. Augusta Witkowskiego w Krakowie, [w:] Wikipedia, http://pl.wikipedia.org/wiki/V_Liceum_Og\%C3\%B3lnokszta\%C5\%82c\%C4\%85ce_im._Augusta_Witkowskiego_w_Krakowie, 6.11.2013.

22 Zob. J. Izdebska, Dziecko w rodzinie u progu XXI wieku. Niepokoje i nadzieje, Białystok 2000, s. 43.

23 Zob. GUS, Jakość życia i spójność społeczna 2011 (wstępna analiza wyników badania ankietowego), http://www.stat.gov.pl/cps/rde/xbcr/gus/ wZ_jakosc_zycia_i_spojnosc_spoleczna_2011.pdf, 12.03.2014. 
Z badań empirycznych wynika, iż 11 badanych to jedynacy, ponad połowa (46 osób) pochodzi z rodziny z dwójką dzieci, 16 badanych wywodzi się z rodzin z trójką dzieci. Dokładnie 4 respondentów pochodzi z rodzin z czworgiem dzieci, natomiast 1 badany z rodziny z pięciorgiem dzieci. Widać tu bardzo wyraźnie, iż rodziny wielodzietne (troje i więcej dzieci) zostały zdominowane przez małodzietne. Według badań CBOS więcej niż dwójkę potomstwa ma zaledwie co czwarty Polak w wieku od 35 do 44 lat (25\%), a także niespełna co trzeci mający od 45 do 54 lat (29\%) ${ }^{24}$. Badania własne wydają się potwierdzać, iż w Krakowie dominują rodziny małodzietne - 57 badanych wychowuje się w takich rodzinach.

Oddziaływać na środowisko badanych uczniów będzie także trwałość związku rodziców. Należy mieć na uwadze, iż relacja między rodzicami jest podstawą rodziny i rzutuje na poczucie bezpieczeństwa, szczęście członków rodziny, a także na wywiązywanie się ze swoich ról oraz rozwój dzieci25.

Tabela 2. Trwałość związku rodziców

\begin{tabular}{|l|l|l|}
\hline L.p. & Wyszczególnienie & Liczba \\
\hline 1 & Są trwałym małżeństwem & 69 \\
\hline 2 & Są w separacji & 0 \\
\hline 3 & Są w okresie przedrozwodowym & 1 \\
\hline 4 & Są rozwiedzeni, ale mieszkają we wspólnym domu & 0 \\
\hline 5 & Są rozwiedzeni i mieszkają oddzielnie & 0 \\
\hline 6 & Nigdy nie zawarli związku małżeńskiego & 2 \\
\hline 7 & Inne & 6 \\
\hline
\end{tabular}

Żródło: opracowanie własne.

Z przytoczonych danych wynika, iż zdecydowana większość rodziców badanych uczniów jest trwałym małżeństwem. Rozwód dotyczy jednej pary rodziców - osoby te są w okresie przedrozwodowym, żadna para rodziców nie jest jak dotąd rozwiedziona.

Tymczasem z doniesień Rządowej Rady Ludnościowej wynika, iż w 2010 r. orzeczono aż 61,3 tysięcy rozwodów. Ponadto na 1000 małżeństw aż 268,5 się rozwiodło ${ }^{26}$. Oznacza to, iż w 2010 roku prawie co czwarte małżeństwo się rozwiodło. Natomiast z moich badań wynika, iż zdecydowana większość związków wśród rodziców badanych trwa. Jeśli już jakieś małżeństwo się rozpada, to przyczyną jest śmierć współmałżonka, na co wskazywali ankietowani, wybierając w tym pytaniu odpowiedź „,inne".

W kontekście omawiania środowiska badanych uczniów warto zatrzymać się jeszcze nad wykształceniem rodziców. Zdecydowana większość matek (65) ma wykształcenie wyższe, przynajmniej magisterskie. Równocześnie ani jedna matka nie skończyła swej edukacji na szkole podstawowej. Wśród ojców wykształcenie wyższe (przynajmniej magisterskie) ma prawie co trzeci badany (53 osoby). Żaden ojciec nie ma wykształcenia podstawowego.

W oparciu o te wyniki można powiedzieć, że kobiety są bardziej wykształcone niż mężczyźni. Ponadto przeważająca większość rodziców badanych uczniów ma wyższe wykształcenie - aż 71 matek i 60 ojców. Według badań GUS, w Polsce jedynie 14,9\% mężczyzn oraz 18,8\% kobiet uzyskało wykształcenie wyższe (stan na 2011 rok) $)^{27}$. Nie sposób zaprzeczyć, iż rodzice badanej młodzieży sytuują się w tej kwestii zdecydowanie powyżej średniej krajowej.

W badaniach przywoływanych przez Ewę Jackowską stwierdzono, że środowisko wychowawcze-inteligenckie, wykształcone, wykonujące cenione w społeczeństwie zawody, mocno oddziałuje na edukację dzieci. Tacy rodzice stawiają swoim dzieciom duże wymagania i mają ogromne oczekiwania co do ich osiągnięć edukacyjnych ${ }^{28}$. Wysokie wykształcenie rodziców badanych uczniów może tłumaczyć przyczyny, zjakich badana młodzież wybrała szkołę tak renomowaną jak V LO w Krakowie.

24 Zob.R. Boguszewski, Komunikatzbadań. Rodzina-jejwspótczesneznaczenieirozumienie, http://www.cbos.pl/SPISKOM.POL/2013/K_033_13. PDF, 15.02.2015.

25 Zob. W. Kądziołka, Dialog źródłem wychowania w rodzinie, Kraków 2012, s. 328.

26 Zob. I. Kowalska, Małżeństwa i Rozwody, [w:] Z. Strzelecki (red.), Sytuacja Demograficzna Polski, Warszawa 2011, s. 64.

27 Zob. GUS, Wyniki Narodowego Spisu Powszechnego Ludności i Mieszkań 2011, http://www.stat.gov.pl/cps/rde/xbcr/gus/lu_nps2011_wyniki_nsp2011_22032012.pdf, 11.03.2014.

28 Zö. E. Jackowska, Środowisko rodzinne a przystosowanie społeczne dziecka w młodszym wieku szkolnym, Warszawa 1980, s. 86. 


\section{RELACJE INTERPERSONALNE DORASTAJĄCYCH Z RODZICAMI W ŚWIETLE BADAŃ WŁASNYCH}

„O efektach wychowania dziecka w rodzinie nie decydują specjalne metody wychowawcze, lecz charakter i formy stosunków rodziców z dziećmi. Dopiero na podłożu określonego stosunku można mówić o wartości i efektywności konkretnej metody lub techniki" ${ }^{29}$. Istotą procesu wychowania jest bowiem relacja, jaka zachodzi między osobami - wychowawcą (rodzicem) a wychowywanym (dzieckiem) ${ }^{30}$.

\section{METODY WYCHOWAWCZE STOSOWANE WOBEC BADANYCH UCZNIÓW}

Warto przyjrzeć się, jakie metody wychowawcze stosują rodzice wobec swoich dorastających dzieci. Odpowiedni dobór metod i właściwe ich praktykowanie przyczyniać będzie się do odniesienia sukcesów wychowawczych i pogłębienia relacji interpersonalnych między rodzicami a dziećmi ${ }^{31}$.

Tabela 3. Metody wychowawcze stosowane przez rodziców

\begin{tabular}{|c|c|c|c|c|c|}
\hline \multirow[t]{2}{*}{ L.p. } & \multirow[t]{2}{*}{ Wyszczególnienie } & \multicolumn{2}{|c|}{ Matka } & \multicolumn{2}{|c|}{ Ojciec } \\
\hline & & czasami & często & Czasami & Często \\
\hline 1 & Nagradzają upominkami & 5 & 21 & 5 & 24 \\
\hline 2 & Oddziałują swoim przykładem & 33 & 8 & 31 & 9 \\
\hline 3 & Stosują szantaż & 5 & 13 & 6 & 11 \\
\hline 4 & Pozbawiają przyjemności & 4 & 13 & 4 & 16 \\
\hline 5 & Udzielają pochwały i zachęty & 29 & 25 & 21 & 27 \\
\hline 6 & Karzą fizycznie (biją) & 0 & 0 & 0 & 0 \\
\hline 7 & Policzkują & 1 & 0 & 1 & 0 \\
\hline 8 & Nie odzywają się do mnie & 1 & 14 & 2 & 6 \\
\hline 9 & Krzyczą, grożą & 4 & 8 & 2 & 12 \\
\hline 10 & Upokarzają przed innymi & 2 & 2 & 1 & 2 \\
\hline 11 & $\begin{array}{l}\text { Słuchają moich wyjaśnień, } \\
\text { dyskutują }\end{array}$ & 38 & 15 & 25 & 19 \\
\hline 12 & $\begin{array}{l}\text { Proszą o poprawę } \\
\text { w zachowaniu }\end{array}$ & 21 & 21 & 15 & 21 \\
\hline 13 & Używają obraźliwych słów & 2 & 3 & 4 & 3 \\
\hline 14 & Inne & 0 & 1 & 0 & 1 \\
\hline
\end{tabular}

Najczęściej stosowaną przez matki metodą wychowania jest dyskutowanie i słuchanie wyjaśnień. Ojcowie najczęściej w wychowaniu oddziałują swoim przykładem -31 badanych wskazało na taką odpowiedź. Najmniej powszechną metodą wychowania - zarówno wśród matek, jak i ojców - są kary fizyczne.

Natomiast z badań opublikowanych w 2014 r. przez M. Śnieżyńskiego wynika, iż w Małopolsce, w dużych miastach, 3,69\% ojców oraz 3,09\% matek stosuje kary cielesne wobec swoich dzieci (uczniów trzecich klas gimnazjalnych). Jednocześnie tylko 2,46\% ojców i 2,87\% matek policzkuje swoje dzieci² ${ }^{32}$ Odnosząc to do badań własnych, można zaobserwować spadek stosowania kar fizycznych przez rodziców.

W oparciu o zamieszczone $\mathrm{w}$ tabeli 3. dane nasuwa się wniosek, że w stosowanych przez rodziców metodach dominują te wychowawczo pożądane, które nie rania, a stwarzają przestrzeń do dialogu i budowania bliskich relacji rodziców z dziećmi. Chodzić będzie tu o: nagradzanie drobnymi prezentami, pozbawianie przyjemności, udzielanie pochwał i zachęt, dyskutowanie i słuchanie wyjaśnień, proszenie o poprawę zachowania. Pozostałe wymienione w tabeli metody (stosowanie szantażu, karanie fizyczne, policzkowanie, nieodzywanie się, krzyczenie i grożenie, upokarzanie przed innymi, używanie obraźliwych słów) zaprzeczają postawie dialogu. Osłabiają relację między rodzicem a dzieckiem, wzbudzają

\footnotetext{
29 M. Ziemska, Postawuy rodzicielskie i ich woptyw na osobowość dziecka, [w]: M. Ziemska (red.), Rodzina i dziecko, Warszawa 1979, s. 167-168.

30 A. Cosmopoulos, dz. cyt., s. 8.

31 M. Łobocki, Teoria wychowania w zarysie, Kraków 2006, s. 196.

32 Zob. M. Śnieżyński, Dialog w rodzinie. Studium teoretyczno-empiryczne, Kraków 2014, s. 190.
} 
poczucie krzywdy, uwłaczają godności dziecka ${ }^{33}$. Ponadto warty zaznaczenia jest fakt, że tak dużą rolę w procesie wychowania badanych osób odgrywa przykład rodzicielski-i to zarówno ojca, jak i matki. Badani zapytani o to, kto jest dla nich wzorem do naśladowania, odpowiadali aż w 53 przypadkach, iż jest to matka, oraz w 50 przypadkach, że taką osobą jest dla nich ojciec. Również Władysław Kądziołka, w latach 2006-2010, na terenie Małopolski badał zagadnienie autorytetu w opinii młodych ludzi (gimnazjaliści, licealiści, studenci). Wówczas to jedynie 4,2\% badanych uważało swoje matki za wzór do naśladowania, zaś 3,9\% badanych - ojców ${ }^{34}$. Wyniki badań W. Kądziołki są rozbieżne z badaniami przeprowadzonymi w V LO. Sugeruje to, iż wybrana grupa badawcza tworzy specyficzne środowisko. Dla maturzystów V LO, w przeciwieństwie wielu innych młodych ludzi z województwa małopolskiego, rodzice stanowią wzór do naśladowania.

Rodzice są dla badanych młodych ludzi wzorem $\mathrm{m}$. in. z następujących powodów: „w jakiś sposób mnie napełniają ochotą do działania i pokazują, że własną pracą można osiągnąć sukces”. Inny uczeń pisał, że chce naśladować rodziców, ponieważ „,są dobrym małżeństwem”, jeszcze inny uzasadniał wybór rodziców na autorytety pisząc: „moi rodzice ciężko pracowali na sukces, który osiągnęli”, inny zaś: „uważam moich rodziców za godnych naśladowania, ponieważ są wierni swoim zasadom".

\section{SPÓJNOŚĆ RODZINY}

Wspólne spędzanie czasu, rozmowy w gronie najbliższych to świetna okazja, by się lepiej poznać, zbliżyć do siebie nawzajem. Według 19 badanych (informacje zebrane z odpowiedzi udzielonych w zdaniu: „Nic tak nie scala rodziny jak...") tym, co przyczynia się do zbliżania członków rodziny do siebie, są dialog i dobre relacje. Respondenci zwracali tutaj uwagę na: , dialog", , dyskusje na ważne tematy”, , "częste rozmowy”, „rozmowę i tolerancję", „miłość”, ,zaufanie", „przyjaźn”", „,miłość i dialog", „szczerość". Natomiast 14 badanych przypisywało zasługę czasowi, który spędza się wspólnie. Osoby te pisały m. in.: „wspólnie spędzane godziny", „bycie razem”, „,spotkania rodzinne”. Spośród badanych 9 osób położyło nacisk na to, iż rodzinę scalają wspólne wyjazdy - „wypad w góry”, „,wspólne wycieczki”, „wspólne wakacje”, „podróże”. Badani wymieniali także spotkania przy stole (7 osób), np. „wspólny obiad”, „kawa i ciastko", „wspólny posiłek”. Natomiast 6 badanych twierdzi, że rodzinę scala coś, co robi ona wspólnie - „wspólne działanie", „wspólna pasja”, „wspólne zajęcia”, „wspólny sport”, „granie w karty”, „zbieranie grzybów”. Również problemy jednoczą rodzinę - deklaruje tak 5 badanych. Będą to np.: ",problemy zdrowotne", „kłopoty, tragedie", „wspólny wróg", „kredyt". Natomiast 3 respondentów twierdzi, że najlepiej scala rodzinę świętowanie - „uroczystości", „urodziny", „,świętowanie sukcesów”. Spośród badanych, 4 osoby wskazały na odpowiedzi, które zaliczyłam do grupy „inne": „,matka”, ,"Zwierzęta”, , prezenty".

Ważnym wskaźnikiem więzi w rodzinie jest współpraca czy współdziałanie ${ }^{35}$. Również wielu młodych ludzi dostrzega wartość wspólnego spędzania czasu z rodzicami. Warto zatrzymać się nad tym, czy w praktyce życia codziennego rodzina robi coś wspólnie - mogą to być np. spacery, wycieczki, wystawy, biwaki itp. Wyniki obrazuje poniższa tabela.

Tabela 4. Wspólne „wyjścia” z rodzicami

\begin{tabular}{|l|l|l|l|}
\hline \multirow{2}{*}{ L.p. } & \multirow{2}{*}{ Wyszczególnienie } & Z matką & Z ojcem \\
\cline { 3 - 4 } & & Liczba & Liczba \\
\hline 1 & Tak & 41 & 37 \\
\hline 2 & Czasami & 25 & 29 \\
\hline 3 & Nie & 10 & 9 \\
\hline & Brak odpowiedzi & 2 & 3 \\
\hline
\end{tabular}

Źródło: opracowanie własne.

Okazuje się, że w co drugiej rodzinie dorastający wychodzą gdzieś wspólnie z matkami. Również z ojcami badani uczęszczają na wycieczki, wystawy itp. (37). Niewielu badanych deklaruje, że w ogóle nie wychodzi z rodzicami -z matką 10 osób, z ojcem 9. Wydaje się to ukazywać, że przeważająca większość młodych ludzi regularnie lub chociaż od czasu do czasu wychodzi gdzieś z rodzicami. Wyniki te są porównywalnie wysokie zarówno dla ojców, jak i matek.

33 Zob. A. Błasiak, dz. cyt., s. 89-95.

34 Zob. W. Kądziołka, dz. cyt., s. 339.

35 W. Kądziołka, dz. cyt., s. 198. 
Oprócz wspólnych wyjść, tym, co przyczynia się do budowania bliskich relacji interpersonalnych, będzie także uprawianie razem z rodzicami różnych form zainteresowań. Przeważająca większość (69 osób) zaznacza, iż dzielą jakieś zainteresowania z ojcem lub z matką bądź obojgiem rodziców. 9 respondentów deklaruje jednak, iż nie znajduje wspólnych pasii z rodzicami. Uczniowie odpowiadali, że z rodzicami przede wszystkim podróżują (38), chodzą na wycieczki i spacery (31). Wysokie wskaźniki mają także wspólne słuchanie muzyki oraz wyjścia do kina - dotyczy 25 z 78 badanych. W oparciu o powyższe dane wydaje się, iż adolescentów wiele łączy z rodzicami.

\section{WSPÓLNE POSIEKI}

Kolejnym elementem przyczyniającym się do dobrych relacji wewnątrzrodzinnych i czynnikiem kształtującym jakość życia rodzinnego (atmosferę domu) jest obyczajowość (codzienna i świąteczna). Świętowanie stwarza okazję do przeżywania wspólnoty, skupiania się na tym, co łączy, a nie dzieli, na wspólnym i radosnym byciu razem. Szczególnym rodzajem takiego wspólnego spotkania się rodziny jest posiłek. Ma to być czas na dobrowolne bycie razem; czas, by otworzyć się na innych członków rodziny, by wspólnie rozmawiać, a zatem też pogłębiać wzajemne relacje ${ }^{36}$. Zatem istotne jest, czy w domach badanych uczniów rodzinne posiłki są codziennościa, a może zdarzają się tylko od święta lub wcale.

Jak wynika z przeprowadzonych badań $\mathrm{w}$ prawie co drugiej rodzinie wspólne posiłki spożywa się tylko $\mathrm{w}$ dni wolne od pracy. Może być to związane z jednej strony z zamieszkiwaniem przez licealistów w bursach, internatach, co wiąże się z tym, iż jedynie w czasie weekendów są $\mathrm{w}$ domu. $Z$ drugiej strony powodem może być praca zawodowa rodziców i konieczność pozostawania w porze obiadów, lunchów poza domem, w miejscu pracy, a także wyjazdy w delegacje. Natomiast 32 badanych uczniów deklaruje, że ich rodziny jedzą wspólnie codziennie. W niewielu przypadkach (5) rodzinne posiłki praktycznie nigdy nie mają miejsca. Wyniki takie zdają się przemawiać za tym, iż w wielu domach dostrzegana jest wartość spotkań przy stole podczas śniadania, obiadu czy kolacji. Godnym pochwalenia staje się fakt, iż mimo pracy zawodowej, obowiązków, nauki tak wiele rodzin potrafi znaleźć czas, by razem spożywać posiłki.

Zgodnie z badaniami Ośrodka Badań Opinii Społecznych, które miały miejsce w 1998 r., ponad połowa Polaków deklaruje, że w ich rodzinach prawie codziennie większość domowników wspólnie jada posiłki. Ponadto częściej takie posiłki występowały w rodzinach mieszkających na wsi ${ }^{37}$.

Spotkanie przy stole powinno być czasem na pogłębianie relacji poprzez rozmowę. Według badań towarzyszy ona rodzinnym posiłkom większości badanych (67). Natomiast niepokojące zachowanie podczas śniadania, obiadu, kolacji to oglądanie TV. Włączony odbiornik telewizyjny rozprasza, przeszkadza w nawiązywaniu kontaktu, rozmów, a zatem utrudnia budowanie dobrych relacji. Zjawisko to dotyczy aż 25 badanych rodzin.

\section{WIĘZI EMOCJONALNE ŁĄCZĄCE DORASTAJĄCYCH Z RODZICAMI}

Tym, co ostatecznie łączy rodzinę w całość, jest ciepło wzajemnych relacji. To więź, jaka łączy dziecko z rodzicami (miłość, czułość, troska, pomoc, odpowiedzialność) oddziałuje nieodwołalnie na życie dziecka i związki, jakie będzie tworzyć zinnymi $^{38}$. Stąd też dla poznania relacji interpersonalnych między dorastającymi a rodzicami ważne są więzi emocjonalne, jakie ich łączą. Oto jak przedstawia się ta kwestia w oparciu o uzyskane wyniki badań.

Tabela 5. Więzi uczuciowe badanych uczniów z rodzicami

\begin{tabular}{|l|l|l|l|}
\hline \multirow{2}{*}{ L.p. } & Wyszczególnienie & Z matką & Z ojcem \\
\cline { 3 - 4 } & & Liczba & Liczba \\
\hline 1 & Bardzo gorące & 18 & 7 \\
\hline 2 & Gorące & 28 & 25 \\
\hline 3 & Ciepłe & 22 & 31 \\
\hline 4 & Obojętne & 6 & 11 \\
\hline 5 & Chłodne & 1 & 0 \\
\hline 6 & Bardzo zimne & 0 & 0 \\
\hline & Brak odpowiedzi & 3 & 4 \\
\hline
\end{tabular}

Zródło: opracowanie własne.

36 Zob. A. Błasiak, dz. cyt., s. 68-69.

37 Zob. J. Izdebska, dz. cyt. s. 202.

38 Zob. J. Jagieła, Relacje w rodzinie a szkoła, Kraków 2007, s. 7-8. 
Więzi uczuciowe dorastających z rodzicami w przeważającej większości są pozytywne. Więzi bardzo gorące, gorące lub ciepłe ma z matkami 68 badanych, z ojcami zaś 63. Jedynie nieliczni deklarowali negatywne (chłodne, bardzo zimne) lub obojętne więzi z rodzicami - 7 osób z matkami i 11 z ojcami.

Jednak, jak twierdzi Irena Obuchowska ${ }^{39}$, trzeba mieć świadomość, że w okresie dorastania rozluźnianie się więzi rodziców z dorastającymi, stopniowe psychiczne oddalanie, wcale nie oznacza rozpadu więzi, a jedynie wskazuje na zmianę w tej relacji i jest czymśn naturalnym i pożądanym. Na tym etapie następuje przejście od relacji dziecięcej zależności do więzi, która oparta jest na partnerstwie. Natomiast w okresie późnej adolescencji (wieku młodzieńczym) relacja z rodzicami i innymi osobami starszymi wiekiem powinna stać się bliska i serdeczna. Dorastający otwierają się na rozmowy z dorosłymi, także na tematy osobiste, oraz chętnie zasięgają ich rady. Konflikty są łagodniejsze i rzadsze, gdyż w tym okresie młodzież wykazuje się większym zrozumieniem dla argumentów rodziców. Zatem w oparciu o uzyskane wyniki wydaje się, że większość badanych uczniów ma już za sobą etap buntu, intensywnych konfliktów z matką czy ojcem i wkroczyła w okres budowania bliskich relacji z rodzicami.

Badania prowadzone przez I. Obuchowską pod koniec XX w. wykazały także, iż przeważnie dorastających i ich rodziców łączy pozytywna relacja. Ponadto z omówionych badań wynika, że dorastający chłopcy i dziewczęta mają lepszą i bliższą więź z matkami niż z ojcami, co wydają się potwierdzać również moje badania empiryczne.

Warto zaznaczyć, iż badana młodzież zdecydowanie częściej wypowiada się o swoich rodzicach w sposób pozytywny niż negatywny. Oto przykładowe wypowiedzi kończące zdanie „Moja mama jest dla mnie...": „wszystkim”, „najważniejsza”, , wzorem postępowania z innymi”, , ,wzorem cierpliwości i oddania”, , „przyjaciółką", „wzorem obywatela i pracownika”, „dobra, czuła, wyrozumiała”, „bardzo bliską osobą”. Niektórzy jednak uważali zupełnie odwrotnie. Osoby takie kończyły zdanie „Moja mama jest dla mnie..." następująco: „irytująca”, , ,ograniczeniem”, , ,emocjonalną istota, którą trzeba rozgryźć i zmanipulować". Niejednokrotnie pojawiały się także odpowiedzi „,mamą", ,"moją mamą".

Natomiast o swoim ojcu („Mój ojciec jest dla mnie...") pisali m. in.: ",doradca, przyjacielem i opiekunem”, ,"najważniejszy", „,Wzorem życiowej zaradności", „partnerem do rozmowy", „wzorem zaradności i pracowitości", „wsparciem”,

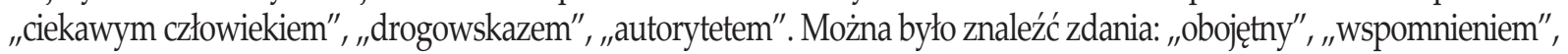
"kimś, z kim nie chciałbym wiele rozmawiać", „rywalem” albo „po prostu tatą", „tatą", „,moim tatą".

\section{DIALOG W OPARCIU O WYNIKI BADAŃ EMPIRYCZNYCH}

Dialog odgrywa istotne znaczenie dla funkcjonowania ogniska domowego, relacji wewnątrzrodzinnych. Stosowany na co dzień jest spoiwem, które przyczynia się do podniesienia jakości tych relacji, daje poczucie zrozumienia, akceptacjï0 Wskazane tutaj wyniki pozwolą poznać, jaki jest wymiar i zakres stosowanego przez rodziców dialogu w opiniach dorastających dzieci (maturzystów V LO). M. Śnieżyński wskazuje na kilka elementów wyzwalających i wspomagających dialog w rodzinie. Według niego najlepsze podłoże dla wystąpienia dialogu w kontaktach rodziców z dziećmi stwarzają $\mathrm{m}$. in.: bardzo dobra atmosfera $\mathrm{w}$ domu, demokratyczny styl wychowania, dialogiczne metody kierowania dzieckiem, nieustanna gotowość rodziców do rozmowy z dzieckiem, autentyczne słuchanie, rozmawianie, dyskutowanie i zaufanie do dziecka, nawiązywanie mocnych więzi emocjonalnych, przyjazny i serdeczny stosunek dzieci do domu rodzinnego ${ }^{41}$.

\section{PARTNERSTWO W WYCHOWANIU}

Podłożem do wejścia w dialog jest relacja oparta na partnerstwie. Styl współpartnerski, zwany też demokratycznym, charakteryzuje się trwaniem z dzieckiem w relacji partnerskiej - jak równy z równym. Styl ten zakłada poszanowanie zdania, uczuć dziecka. Towarzyszy mu atmosfera przyjaźni, wsparcia, życzliwości, zaufania. Oparty jest na współpracy i rozmowie oraz bliskich relacjach interpersonalnych. Rodzice pozwalają dziecku na samodzielność, a kiedy potrzebuje ono pomocy - wspomagaja. Jeśli natomiast dziecko popełnia błąd, rodzice nie odrzucają go, a wskazują kierunek poprawy. Dziecku okazywane są miłośći zainteresowanie. Wymagania rodziców są dostosowane do jego wieku i możliwości. Młody człowiek jest doceniany i chwalony ${ }^{42}$.

Styl współpartnerski nabiera na znaczeniu w okresie dorastania dziecka, kiedy posiada ono już wiedzę o tym, co jest pożądane, dobre, a co wręcz odwrotnie. Wówczas rodzic powinien dać adolescentowi szansę na wypowiadanie swoich

\footnotetext{
39 I. Obuchowska, Adolescencja, [w:] B. Harwas-Napierała, J. Trempała (red.), Psychologia rozwoju człowieka. T.2, Warszawa 2003, s. 178-179, 187.

40 Zob. M. Śnieżyński, Zarys..., dz. cyt., s. 131-133.

41 M. Śnieżyński, Dialog..., dz. cyt., s. 146-147.

42 Zob. A. Błasiak, dz. cyt., s. 81-84.
} 
racji, uczestniczenie w podejmowaniu decyzji. Powinien to być czas budowania kontaktów o charakterze współpartnerstwa, oparty o dialog. W dialogu rodziców z dorastającą młodzieżą nie może być zatem miejsca dla zachowań takich jak nakazywanie, moralizowanie, komenderowanie, perswadowanie, groźby, szantaże, osądzanie, krytykowanie, zawstydzanie, wyśmiewanie, bo te wykluczają współpartnerstwo $0^{43}$. Poniższa tabela przedstawia, jakich stylów w wychowaniu doświadczają badani uczniowie.

Tabela 6. Style wychowania preferowane przez rodziców

\begin{tabular}{|l|l|l|l|}
\hline \multirow{2}{*}{ L.p. } & Wyszczególnienie & Matka & Ojciec \\
\cline { 3 - 4 } & & Liczba & Liczba \\
\hline 1 & Styl autorytarny & 7 & 11 \\
\hline 2 & Styl współpartnerski & 22 & 19 \\
\hline 3 & Styl liberalny & 12 & 13 \\
\hline 4 & Styl niekonsekwentny & 5 & 1 \\
\hline 5 & Style wzajemnie się przeplatają & 25 & 24 \\
\hline 6 & Nie dostrzegam żadnego stylu & 6 & 7 \\
\hline & Brak odpowiedzi & 1 & 3 \\
\hline
\end{tabular}

Źródło: opracowanie własne.

Najpowszechniej stosowanym przez rodziców stylem wychowania jest styl mieszany (kombinacja różnych stylów). Nieco mniej powszechnie stosowanym, zarówno przez matki, jak i ojców, jest styl współpartnerski, który pojawia się w sposobie wychowania 22 matek oraz 19 ojców. Około jedna szósta ojców i matek preferuje styl liberalny w wychowaniu. Jeszcze rzadziej stosowany wobec badanej młodzieży jest styl autorytarny - jedynie przez 7 matek i 11 ojców. Najrzadziej w rodzinach badanych uczniów pojawia się styl niekonsekwentny.

W oparciu o uzyskane wyniki można zauważyć, iż partnerstwo w procesie wychowania młodzieży pojawia się zbyt rzadko. Jednocześnie wyniki badań sugerują że nie ma jednego stylu wychowania, który jednoznacznie dominowałby w procesie wychowania dorastających dzieci. Sytuacja taka może wynikać stąd, że rodzice mają trudność w budowaniu partnerskich relacji ze swoimi dziećmi. Bardziej naturalne jest dla nich pozostanie w hierarchicznej relacji. Między rodzicami a dziećmi istnieje bowiem szereg różnic - np. wieku, wielości doświadczeń. Rodzice górują nad dorastającymi dziećmi pozycją społeczna, zawodową. Ponadto z racji bycia rodzicami przypisane mają określone obowiązki, uprawnienia, a także ciąży na nich odpowiedzialność prawna za dzieci" ${ }^{44}$.

\section{SPOSOBY KOMUNIKOWANIA SIĘ RODZICÓW Z DZIEĆMI}

W literaturze zwraca się uwagę na dwa typy wzorców komunikowania się rodziców z dziećmi: rozmawianie z dzieckiem oraz mówienie do dziecka. Rodzice rozmawiający z dzieckiem podejmują konwersację na temat wzajemnych problemów. Zezwalają potomkowi na ujawnianie poglądów, opinii, uczuć, liczą się z jego zdaniem. Taka postawa rodziców sprzyja zwierzeniom, zachęca do rozmów, stwarza warunki równości do prowadzenia dialogu. Z kolei rozmowa typu „mówienie do dziecka" przeważnie przybiera formę upominania, krytykowania, moralizowania, zakładania z góry, że tylko stanowisko rodzica jest słuszne. Tworzy się autorytarny układ - rodzic dominuje, a dziecko ma się dostosowaćá . Warunkiem udanego dialogu wychowawczego jest uznanie przez rodzica godności osobowej pociechy i traktowanie go na równi. Dziecko nie może być traktowane niczym rzecz, która jest poddana pragnieniom, życzeniom czy poleceniom osoby dorosłej ${ }^{46}$.

Badani uczniowie zostali zapytani, czy prowadzą z rodzicami prawdziwy dialog, w którym ma miejsce autentyczne słuchanie się nawzajem obu stron, dyskutowanie, gdzie zwycięża logika argumentacji, a nie pozycja (rodzic ma zawsze rację). Uzyskane wyniki badań sugerują iż dorastający częściej prowadzą prawdziwy dialog z matkami (47) niż z ojcami (32). Aż 36 badanych wskazuje, że jedynie czasami relacje z ojcami są oparte o dialog, podczas gdy z matkami -21. Brak występowania prawdziwego dialogu zarówno z matka, jak i z ojcem, zaznacza co dziesiąty badany uczeń.

43 Zob. M. Śnieżyński, Zarys..., dz. cyt., s. 143-144.

44 Zob. U. Ostrowska, Relacje interpersonalne wedukacji jako przedmiot badan, [w]:U. Ostrowska (red.), Aksjologiczne aspekty relacji interpersonalnych w edukacji, Kraków 2002, s. 120.

45 Zob. B. Harwas-Napierała, Komunikacja interpersonalna wo rodzinie, Poznań 2006, s. 25.

46 Zob. W. Kądziołka, dz. cyt., s. 402. 
Jednocześnie ponad połowa badanych (48) jest zadowolona z dialogu z matką. Z kolei pozytywne opinie co do dialogu z ojcem pojawiają się w połowie przypadków. Jednak stosunkowo często dorastający nie są zadowoleni z dialogu $\mathrm{z}$ rodzicami $-10 \mathrm{z}$ matką oraz 13 z ojcem.

Chcąc przyjrzeć się dokładniej odpowiedziom udzielonym przez uczniów (w zdaniach: „O moim dialogu z matka mogę powiedzieć, że..." oraz „O moim dialogu z ojcem mogę powiedzieć, że..."), można przytoczyć niektóre ich opinie.

Pozytywne wypowiedzi dotyczące dialogu z matką to $\mathrm{m}$. in.: ",chętnie go podejmuję", , ,jest potrzebny i kojący", , dobrze się dogadujemy", ,"kształtuje się wzorowo", , ,jest szczery", , ,jest otwarty", ,jest swobodny". Wśród negatywnych opinii co do dialogu z matką pojawiły się następujące stwierdzenia: „Zwykle mnie nie rozumie", , ,jest przeze mnie unikany" albo „,męczy mnie", „"często nudzi” czy też ,jest nierówny”. Do grupy „inne” zakwalifikowałam m. in. stwierdzenia: „,emocjonalny", , ,jest zmienny", , „trwa długo", ,,staram się czasem go nawiązać, , „próbujemy ale nie wychodzi” , „czasem nic nie wnosi".

Z kolei przy opisie dialogu z ojcem można było znaleźć następujące pozytywne wypowiedzi: ,jest interesujący", , ,jest taki jak być powinien", „mówimy sobie o wszystkim”, , dogadujemy się" lub ,jest bardziej rzeczowy niż z matką", ,jest zawsze konstruktywny", ",gadamy jak równy z równym", ",lubię z nim rozmawiac'” czy też ,jest otwarty", , ,jest budujący", , ,jest szczery". Natomiast część z respondentów wskazała na negatywne aspekty ich dialogu z ojcem: „bywa trudny", „zdarza się rzadko”, „istnieje, ale powinien być leszy”, „nie bardzo mamy o czym rozmawiać", „często się kłócimy”, „bywa chłodny”, „przedłuża się bez sensu”, a nawet „nie istnieje”. W grupie „inne” pojawiły się: „kłócimy się, ale potrafimy się dogadac', , ,jest trochę inny niż z mamą", , ,jest normalny, ale rozmawiamy niezbyt często", , jest śmieszny", , ,jest różny", , ,jest wystarczający", , jest przeciętny".

\section{SZACUNEK DLA PARTNERA DIALOGU}

Dla występowania dialogu ważne jest, aby obie strony w rozmowie miały prawo głosu, by ich zdanie było respektowane przez drugą stronę. Tylko jeśli szanujemy zdanie drugiej osoby, jesteśmy w stanie zrezygnować z narzucania jej swoich przekonań. Jarosław Jagieła pisze, iż 80\% młodych ludzi między 14 a 19 rokiem życia oczekuje od swych opiekunów stawiania im poważnych wyzwań oraz pozostawiania prawa do podejmowania zasadniczych decyzji i szanowania tych wyborów ${ }^{47}$.

Wyniki moich badań w kwestii szanowania przez rodziców opinii i decyzji dorastających dzieci dowodza, że większość badanych (62) ma poczucie, iż matka liczy się z ich zdaniem. Natomiast 52 ojców daje swoim dzieciom takie poczucie. Znikomy procent osób twierdzi, że czuje, iż dla rodziców ich zdanie się nie liczy. Ukazuje to, że matki bardziej aniżeli ojcowie liczą się z decyzjami swoich dzieci.

Odwróćmy jednak sytuację - czy badani dorastający uczniowie liczą się ze zdaniem rodziców? Jak pokazują moje badania, przy podejmowaniu decyzji uwzględnia stanowisko matki 52 badanych, ojca zaś - 50. Czasami ze zdaniem matki czy ojca liczy się aż 24 badanych. Natomiast znikomy procent osób nie liczy się z opiniami swoich rodziców.

Powyższe wyniki pozwalają mi wysnuć przypuszczenie, że dialog w rodzinach badanych uczniów przeważnie oparty jest na wzajemnym szacunku dla zdania, opinii, decyzji drugiej ze stron.

Natomiast według badań M. Śnieżyńskiego (przytoczone badania prowadzone były w dużych miastach, na uczniach trzecich klas gimnazjalnych) wskaźniki liczenia się rodziców ze zdaniem dzieci i odwrotnie są niższe od tych, które pokazują moje badania. Badania M. Śnieżyńskiego ukazują, że ze zdaniem dorastających dzieci liczy się 48,66 \% ojców oraz $56,67 \%$ matek ${ }^{48}$. Sugeruje to, że wraz z wiekiem dziecka zmienia się poziom szanowania przez rodziców jego opinii, zdania, decyzij.

\section{CZESTTOTLIWOŚć I DŁUGość ROzMów}

Nie należy jednak pomijać faktu, że aby dialog w ogóle mógł istnieć, rodzice i dzieci muszą ze sobą rozmawiać. Warunkiem występowania dialogu jest częsta, spokojna rozmowa rodziców z dziećmi na różne tematy ${ }^{49}$. Zatem ważne będzie, jak często i ile czasu w badanych rodzinach poświęca się na rozmowy. Pomoże zobrazować to poniższa tabela.

\footnotetext{
47 J. Jagieła, dz. cyt., s. 77.

48 Zob. M. Śnieżyński, Dialog..., dz. cyt., s. 220.

49 W. Kądziołka, dz. cyt., s. 402.
} 
Tabela 7. Częstotliwość rozmów badanych uczniów z rodzicami

\begin{tabular}{|l|l|l|l|}
\hline \multirow{2}{*}{ L.p. } & Wyszczególnienie & Z matką & Z ojcem \\
\cline { 3 - 4 } & & Liczba & Liczba \\
\hline 1 & Prawie codziennie & 27 & 10 \\
\hline 2 & Kilka razy w tygodniu & 21 & 15 \\
\hline 3 & Raz na tydzień & 4 & 13 \\
\hline 4 & Kilka razy w miesiącu & 2 & 8 \\
\hline 5 & Prawie nigdy & 7 & 13 \\
\hline 6 & Zawsze, gdy tylko zachodzi potrzeba & 17 & 16 \\
\hline
\end{tabular}

Najczęściej wybieraną przez badanych opcja jeśli chodzi o częstotliwość rozmów z matka, jest określenie „prawie codziennie" - wskazało tak 27 uczniów. Natomiast zapytani o rozmowy z ojcami dorastający najczęściej wybierali odpowiedź - „zawsze, gdy tylko zachodzi taka potrzeba” (16).

Według badań W. Kądziołki przeprowadzonych w Małopolsce między 2006 a 2010 r., 33,6\% badanych młodych ludzi rozmawia z ojcami prawie codziennie lub zawsze, gdy odczuwają potrzebę. Z matką w tych dwóch przypadkach (codziennie lub kiedy zachodzi potrzeba) rozmawia zdecydowanie więcej badanych $-66,3 \% 50$.

J. Jagieła przywołuje niedawno przeprowadzone wśród tysiąca dorosłych mieszkańców Warszawy i Lublina badania, według których przeciętny polski ojciec poświęca swojemu dziecku ok. 7 minut dziennie ${ }^{51}$. Tymczasem niezwykle ważne jest, żeby dziecko w ciagu dnia miało rodzica tylko dla siebie; by był taki czas (a im więcej, tym lepiej), w którym rodzic i dziecko mogą autentycznie pobyć razem (bez „rozpraszaczy” takich jak np. telewizja, gazeta, telefon, obowiązki domowe) i szczerze porozmawiaćs 2 .

Z moich badań wynika, iż prawie 30\% matek oraz aż co drugi z ojców rozmawia ze swoim dorastającym dzieckiem nie dłużej niż 15 minut w ciaggu dnia. Natomiast pytanie z testu zdań niedokończonych („Najczęściej rozmawiam w domu z..."), mające na celu zbadanie, z kim dorastający najczęściej rozmawiają w domu, daje informację, że w połowie przypadków taką osobą jest matka. Jedynie 5 badanych wskazało na ojca. Wyniki takie wydają się ukazywać, że ojcowie badanych maturzystów poświęcają bardzo niewiele czasu w ciagu dnia - wyraźnie mniej niż matki - na rozmowę ze swoimi dziećmi.

Dorastający zapytani o przyczyny braku rozmów z rodzicami odpowiadali np., że: „im mniej wiedza, tym mniej się martwią i lepiej się dogadujemy - nie kłócimy się", , jestem atakowany (słownie) za wszystko, wytykane są moje błędy we wszystkim co robię", ,"ponieważ nie czuję potrzeby". Inne powody to „zapracowanie rodzica, brak czasu” albo „brak inicjatywy rodziców i zainteresowania z ich strony".

Wielu badanych uczniów przypisuje pozytywną wartość rozmowom z rodzicami. Rozmowy o troskach, sukcesach, trudnościach: „sprawiaja, że dowiadujemy się więcej o sobie”, ,,są budujące i pomagają dzieciom w trudnych chwilach”, „bardzo je lubię, mam poczucie, że rodzicom mogę powiedzieć wszystko”. Inne wypowiedzi to: „dzięki nim czuje, że łączy nas więź porozumienia” albo „uważam, że bardzo pomagają mi radzić sobie z życiem i odnajdywać swoją drogę, pozwalają na poukładanie własnych myśli”. Jeden uczeń napisał: „dają mi poczucie, że nie jestem sam”, inny zaś: „są prawdziwą lekcją życia".

\section{OTWARTOŚĆ NA ROZMOWE}

Kolejnym ważnym wyznacznikiem dialogu, o czym była mowa już wcześniej, jest otwartość rodziców na dialog z dorastającymi dziećmi. Poniższa tabela ukazuje najbardziej typowe w rodzinach badanych uczniów reakcje matki czy ojca w sytuacji, kiedy dorastający pragnie z nimi porozmawiać.

Zdecydowana większość rodziców reaguje pozytywnie i wykazuje chęć do rozmowy. Badani wskazywali przeważnie, że rodzice są zawsze otwarci na takie rozmowy czy też chętnie podtrzymują temat rozmowy i zawsze są gotowi im

50 Tamże, s. 402.

51 J. Jagieła, dz. cyt., s. 80.

52 Zob. A. Błasiak, dz. cyt., s. 59-60. 
pomóc, doradzić. Natomiast na negatywne reakcje rodziców wskazuje w odniesieniu do matek 19 osób, a w odniesieniu do ojców 28 osób. Te negatywne, niepożądane i świadczące o braku otwartości na rozmowę zachowania rodziców to: udawanie, że się nie słyszy dziecka; zasłanianie się brakiem czasu; zmienianie tematu; wysłuchiwanie, ale bez podtrzymywania rozmowy lub z narzucaniem swojego zdania jako jedynego właściwego.

Tabela 8. Typowe reakcje rodziców na propozycję rozmowy

\begin{tabular}{|l|l|l|l|}
\hline \multirow{2}{*}{ L.p. } & Wyszczególnienie & Matka & Ojciec \\
\cline { 3 - 4 } & & Liczba & Liczba \\
\hline 1 & Są zawsze otwarci na takie rozmowy & 57 & 46 \\
\hline 2 & Udają, że nie słyszą & 1 & 1 \\
\hline 4 & Zasłaniają się brakiem czasu & 0 & 1 \\
\hline 5 & Zmieniają temat rozmowy & 0 & 1 \\
\hline 6 & Wysłuchują ale nie podtrzymują rozmowy & 7 & 10 \\
\hline 7 & Wysłuchują ale zawsze narzucają swoje zdanie & 11 & 15 \\
\hline
\end{tabular}

* Łączna wartość tego zestawienia przekracza 78, gdyż niektórzy badani zaznaczali więcej niż jedną odpowiedź.

Źródło: opracowanie własne.

Otwartość rodziców na rozmowy świadczyć będzie o chęciach, jakie mają rodzice-a zatem czy w ogóle chcą i próbują podejmować, podtrzymywać dialog ze swoimi dziećmi. Zwróćmy jednak uwagę, że nad wyraz często badana młodzież zaznacza, iż ich rodzice narzucają im swoje zdanie - 11 matek oraz 15 ojców. Takie nastawienie wyklucza prawdziwy dialog i sugeruje autorytarny styl wychowania.

\section{SŁOWEM PODSUMOWANIA}

Podsumowując uzyskane wyniki badań warto zaznaczyć, iż maturzyści V Liceum Ogólnokształcącego im. Augusta Witkowskiego w Krakowie żyją w specyficznym środowisku wychowawczym. Przemawia za tym chociażby fakt, że jedynie znikoma część badanych ma za sobą doświadczenia związane z rozwodem rodziców. Cechą charakterystyczną rodzin, których dzieci zostały objęte badaniami, jest wyższe wykształcenie rodziców. Badani uczniowie w przeważającej większości żyją w środowisku inteligenckim (wyższe wykształcenie posiada 71 matek oraz 60 ojców). Ponadto zdecydowana większość rodzin ma bardzo dobrą sytuację materialna, w której brak jest kłopotów finansowych (71). Stwarza to dogodne warunki do wychowania i rozwoju.

Na skutek badań empirycznych można dojść do przekonania, że dorastające dzieci (ok. 19 r. ż.) i ich rodziców przeważnie łączą pozytywne relacje interpersonalne. 68 badanych określa więzi z matkami jako bardzo gorące, gorące lub ciepłe, z ojcami zaś - przeszło 63. Za dobrymi relacjami przemawia także fakt, że przeważająca większość badanych spędza czas wspólnie z rodzicami. 66 respondentów wychodzi (np. do kina, teatru, muzeum, na biwaki, spacery) regularnie lub chociaż od czasu do czasu - zarówno z matkami, jak i z ojcami. Dodatkowo zdecydowana większość badanych (69) dzieli jakieś wspólne zainteresowania z ojcem lub z matką bądź obojgiem rodziców (m. in. podróże, muzyka, wycieczki, kino). Pokazuje to, iż dorastający i ich rodzice żyją razem ze sobą a nie tylko obok siebie. Nie sposób pominąć, że dla większości maturzystów V LO rodzice stanowią wzór do naśladowania (matka dla 53 osób, ojciec dla 50 osób). Bliskie, pozytywne relacje stają się najdogodniejszym podłożem dla przyjęcia postawy dialogu w procesie wychowania.

W wielu rodzinach, których dorastające dzieci brały udział w badaniu, dialog jest sposobem na wspólne życie. Ponad połowa badanych (48) pisze pozytywnie o dialogu z matka; z ojcem zaś - 39 respondentów. Trzeba jednak zaznaczyć, że dorastający częściej prowadzą prawdziwy dialog z matkami (47) niż z ojcami (32).

Dialog pomiędzy rodzicami i dziećmi nie może istnieć bez partnerskiego układu i podmiotowego traktowania się nawzajem. Tymczasem jedynie 22 matki oraz 19 ojców stosuje w wychowaniu dorastających dzieci styl współpartnerski, a tym samym traktuje potomka jak równego partnera dialogu. Dialog $\mathrm{w}$ rodzinach badanych uczniów przeważnie oparty jest na wzajemnym szacunku dla zdania, opinii, decyzji drugiej ze stron. Rodzice najczęściej liczą się ze zdaniem/ decyzjami dorastających (62 matki oraz 52 ojców). W sytuacji, kiedy badani chcą z rodzicami porozmawiać, zdecydowanie częściej rodzice wykazują pozytywne postawy/reakcje na propozycję rozmowy niż te negatywne. Zatem wydaje się, że 
rodzice chcą i próbują podtrzymywać dialog ze swoimi dziećmi. Częstotliwość i ilość czasu poświęconego na rozmowy badanych maturzystów z rodzicami często pozostawiają jednak wiele do życzenia. Otóż 44 matki oraz jedynie 26 ojców rozmawia ze swoimi dziećmi codziennie lub zawsze, kiedy zachodzi potrzeba. Pozostałe 34 matki oraz 53 ojców rozmawia z dorastającymi dziećmi kilka razy w tygodniu lub rzadziej (w tym aż 7 matek i 13 ojców prawie wcale nie rozmawia ze swoimi dziećmi). Zatem matki konwersują ze swoimi dziećmi częściej niż ojcowie. Dodatkowo 23 matki oraz aż co drugi z ojców rozmawia ze swoim dorastającym dzieckiem nie dłużej niż 15 minut w ciągu dnia. Pokazuje to, że wielu ojców poświęca bardzo niewiele czasu w ciągu dnia, wyraźnie mniej niż matki, na konwersację ze swoimi dziećmi. Stąd też można wnioskować, że nie we wszystkich rodzinach wziętych pod uwagę w badaniu prowadzony jest dialog. W niektórych rodzinach należałoby nad nim pracować, skupiając się zwłaszcza na długości trwania i częstotliwości rozmów, a także uwzględnianiu w większym zakresie stylu współpartnerskiego w procesie wychowania dorastających dzieci.

\section{Bibliografia:}

[1] Bauman T., Pilch T., Zasady badań pedagogicznych. Strategie ilościowe i jakościowe, Warszawa 2001.

[2] Błasiak A., Oddzialywwania wychowazwcze w rodzinie. Zagadnienia woybrane, Kraków 2012.

[3] Cosmopoulos A., Edukacja jako relacja interpersonalna - spojrzenie aktualne, „Kwartalnik Pedagogiczny” 2001, nr 2.

[4] Harwas-Napierała B., Komunikacja interpersonalna w rodzinie, Poznań 2006.

[5] Izdebska H., Rodzina i jej funkcje wychowawcze, [w:] Pomykało W. (red.), Encyklopedia pedagogiczna, Warszawa 1993.

[6] Izdebska J., Dziecko w rodzinie u progu XXI wieku. Niepokoje i nadzieje, Białystok 2000.

[7] Jackowska E., Środowisko rodzinne a przystosowanie społeczne dziecka w młodszym wieku szkolnym, Warszawa 1980.

[8] Jagieła J., Relacje w rodzinie a szkoła, Kraków 2007.

[9] Kałużna-Wielobób A., Wielobób J. K., Międzypokoleniowa transmisja konfliktów w rodzinie, „Społeczeństwo i Rodzina” 2013, nr 35.

[10] Kądziołka W., Dialog źródtem wychowania w rodzinie, Kraków 2012.

[11] Kowalska I., Małżeństwa i Rozwody, [w:] Strzelecki Z. (red.), Sytuacja Demograficzna Polski, Warszawa 2011.

[12] Kruczkowska V., Komunikacja z nastolatkiem, „Wychowawca” 2012, nr 7-8.

[13] Łobocki M., Metody i techniki badań pedagogicznych, Kraków 2000.

[14] Łobocki M., Teoria wychowania w zarysie, Kraków 2006.

[15] Łobocki M., Wprowadzenie do metodologii badań pedagogicznych, Kraków 2004.

[16] Obuchowska I., Adolescencja, [w:] Harwas-Napierała B., Trempała J. (red.), Psychologia rozwoju człowieka. T.2, Warszawa 2003.

[17] Ostrowska U., Relacje interpersonalne w edukacji jako przedmiot badan,, [w]: Ostrowska U. (red.), Aksjologiczne aspekty relacji interpersonalnych wedukacji, Kraków 2002.

[18] Śnieżyński M., Dialog w rodzinie. Studium teoretyczno-empiryczne, Kraków 2014.

[19] Śnieżyński M., Zarys dydaktyki dialogu, Kraków 1997.

[20] Tyszka Z., Rodzina wspótczesna - jej geneza i kierunki przemian, [w:] Ziemska M. (red.), Rodzina wspótczesna, Warszawa 1999.

[21] Ziemska M., Postawy rodzicielskie i ich woptyw na osobowość dziecka, [w]: Ziemska M. (red.), Rodzina i dziecko, Warszawa 1979.

\section{Netografia:}

[22] Boguszewski R., Komunikat z badań. Rodzina-jej wspótczesne znaczenie i rozumienie,

http://www.cbos.pl/SPISKOM.POL/2013/K_033_13.PDF, 15.02.2015.

[23] Dzielnica Pierwsza Miasta Krakowa, http://www.dzielnica1.krakow.pl/informacje-ogolne/2-informacja-ogolna-o-dzielnicy-i, 06.11.2013.

[24] GUS, Jakość życia i spójność społeczna 2011 (wstępna analiza wyników badania ankietowego), http://www.stat.gov.pl/cps/rde/xbcr/gus/wz_jakosc_ zycia_i_spojnosc_spoleczna_2011.pdf, 12.03.2014.

[25] GUS, Wyniki Narodowego Spisu Powszechnego Ludności i Mieszkań 2011, http://www.stat.gov.pl/cps/rde/xbcr/gus/lu_nps2011_wyniki_ nsp2011_22032012.pdf, 11.03.2014.

[26] Informator o Krakowskich Szkotach Ponadgimnazjalnych na rok szkolny 2011/2012, http://www.portaledukacyjny.krakow.pl/files/informator_o_ krakowskich_szkolach_ponadgimnazjalnych_na_rok_szkolny_2011-2012.pdf, 6.11.2013.

[27] O rodzinie stów parę, http://www.cellulit24.pl/wspolne-spedzanie-czasu.php, 20.02.2015.

[28] Podział administracyjny Krakowa, http://pl.wikipedia.org/wiki/Podzia\%C5\%82_administracyjny_Krakowa, 06.11.2013.

[29] Śnieżyński M., Dialog w rodzinie, http://www.opoka.org.pl/biblioteka/Z/ZR/wam_2012_dialog_02.html\#p19, 21.05.2013.

[30] V Liceum Ogólnokształcace w Krakowie, http://www.v-lo.krakow.pl/o-szkole/historia-szkoly, 06.11.2013.

[31] V Liceum Ogólnokształcace im. Augusta Witkowskiego w Krakowie, Wikipedia,http://pl.wikipedia.org/wiki/V_Liceum_Og\%C3\%B3lnokszta\%C5\%82c\%C4\%85ce_im._Augusta_Witkowskiego_w_Krakowie, 06.11.2013. 